\title{
Minimizing Antioxidant Damage of Purple Sweet Potato var Antin 3 in Vacuum Packaging
}

\author{
Abd. Azis Hasan ${ }^{1 *}$, Nur Hidayat ${ }^{2}$, Sri Kumalaningsih ${ }^{2}$ \\ ${ }^{1}$ Master Program of Agricultural and Industrial Technology, Faculty of Agricultural Technology, University of Brawijaya, \\ Malang, Indonesia \\ ${ }^{2}$ Program of Agricultural and Industrial Technology, Faculty of Agricultural Technology, University of Brawijaya, Malang, \\ Indonesia
}

\begin{abstract}
The aim of this research is to find out the best immersion time in liquid nitrogen and the thickness of the packaging plastic to minimize the antioxidant damage of purple sweet potato during storage process. This research is conducted by using a factorial experiment in a randomized block design with two factors. In this research, first factor is the immersion time $(0 ; 50 ; 60 ; 70$ seconds), the second factor is the thickness of plastic $(0.07$ and $0.10 \mathrm{~mm})$. The result of this research showed that the best immersion time is 70 seconds, while the best plastic thickness is $0.1 \mathrm{~mm}$. The interaction of these two factors is the most effective to prevent antioxidants damage of purple sweet potato chips during 1 month storage.
\end{abstract}

Keywords: antin 3, antioxidants, multilayer, vacuum packaging

\section{INTRODUCTION}

Sweetpotato includes as tubers that has a high potential because its high domestic demand. Based on Indonesian Ministry of Agriculture, on 2013, the national wide of sweetpotato harvest area is 161,850 hectar with $2,386,729$ ton of national production, while the total export of sweetpotato is 9,796.844 ton [1]. Thuse, most of sweetpotato production is used for domestic need.

Purple sweet potato is a kind of sweet potato that has much benefit, especially for health because its antioxidant substance. That character is strongly related to the purple pigment that represents anthocyanin substance as antioxidant. Purple sweet potato contains compounds that function as antioxidants, such as phenolic compounds and anthocyanins [2]. The content of phenolic compounds in purple sweet potato is 4.9 to 6.7 higher than the yellow and white potatoes [3] and from 2.5 to 3.2 higher than blueberries [4].

Purple sweet potato antin 3 varieties have purple pigment from the main tuber to the peel. For that reason, this variety can be processed as antioxidant-beneficial products such as natural dye, supplement for health, flour, or as intermediate product [5].

\footnotetext{
* Correspondence author:

Abd. Azis Hasan

Email : abdazizhasan@poligon.ac.id

Address : Agricultural and Industrial Technology Program, University of Brawijaya, Jl. Veteran Malang, 65145
}

The obstacle in processing purple sweet potato is the difficulty in maintaining antioxidant substance (anthocyanin) as purple pigment in purple sweetpotato. Physical and enzimatical damage in purple sweet potato will influence antioxidant substance damage. Freezing is one of method to prevent the damage of food product during storage. There are many kinds of freezing method for food product which is used based on the product. One of them is fast-freezing-process using liquid nitrogen [6].

The growth of ice crystals is one of the factors that influence the quality of frozen foods. If freezing occurs slowly then allow the ice crystals grow so that the cells become damaged and the tissue can not be thawed back again like the original because the formed ice crystals will penetrate and injure the tissue material. Rapid freezing using liquid nitrogen resulted in formation of less ice crystals both in the extracellular and intracellular regions. Thus prevent the damage on nutritions, one of which is the antioxidant content [6]. Liquid nitrogen (boiling point $-196^{\circ} \mathrm{C}$ ) has become very important lately due to its role in quick freezing food (rapid freezing). This method reduces the oxidation on the surface of the food that is not packaged and the loss of water from the food material [7].

Storaged food product, especially purple sweet potato has high risk of contamination. The contamination of other substance will damage the antioxidant. Therefore, packing system is needed which functions as protector for food 
product from physical damage and obstruct the quality damage [8].

Damaging prevention of antioxidant substance, especially for purple sweet potato is not widely observed. Therefore, this research was aimed to assess the combination between immersion time in nitrogen liquid and thickness of packing plastic. It is expected to minimize the damage of antioxidant substance in purple sweetpotato.

\section{MATERIALS AND METHODS}

In this research, purple sweet potato tuber was cut into rounded shape chips with thickness of $\pm 1 \mathrm{~cm}$. In order for the purple sweet potato chips are not damaged during storage, then the multilayer plastic packaging used with two levels of thickness: $0.07 \mathrm{~mm}$ and $0.10 \mathrm{~mm}$. After packaging, freezing was done quickly with the treatment of immersion in liquid nitrogen at four levels of times, i.e. 0 seconds, 50 seconds, 60 seconds, and 70 seconds. The treatment was done with three replications. Thereafter, purple sweet potato chips stored in a freezer at a temperature of $-25^{\circ} \mathrm{C}$ for one month.

This research used quantitative method. The measuring parameters are antioxidant activity used DPPH method [9], while total anthocyanin content used differencial pH method [10]. Total phenol content used Follin-Ciocalteau method [11]. Total dissolved solids content used refractometer based on AOAC [12], and hue saturation value used color reader [13]. The measuring parameter procedures were:

\section{Measuring antioxidant activity with DPPH}

Purple sweet potato chip was crushed and weighed about $20 \mathrm{~g}$, taken into volumetric flask $100 \mathrm{mLl}$, extracted by additional $\mathrm{HCL} 1 \%$ in methanol until it reached the limit mark. After homogenized, the sample was shook for 4 hour and filtered by filter paper, and filtrate was produced. The filtrate centrifuged for $10 \mathrm{~min}$ at 4,000 rpm.

Total $0.1 \mathrm{~mL}$ filtrate was measured, then added methanol $96 \%$ as much as $5 \mathrm{ml}$ and then performed vortex to dissolve the sample. Extracts were centrifuged at a speed of 4,000 rpm for 10 min to separate the extract. A total of $4 \mathrm{~mL}$ supernatant was taken and added to $1 \mathrm{~mL}$ of 1.1 diphenil-2-picrylhydrazil (DPPH) $0.2 \mathrm{mMol}$, set for $10 \mathrm{~min}$. Then the absorbance was measured at a wavelength of $517 \mathrm{~nm}$, but previously control absorbance was measured. Control is made by added $1 \mathrm{~mL}$ of $1.1 \mathrm{DPPH} 0.2 \mathrm{mMol}$ into $4 \mathrm{~mL}$ of methanol. Free radical scavenger activity as DPPH color presentage deficiency, calculated with the formula:

Antioxidant activity $=100 \times 1-\frac{\text { sample absorbance }}{\text { blank absorbance }}$

\section{Anthocyanin measurement with differential pH}

Results of filtrate pipetted $1 \mathrm{~mL}$, then put 10 $\mathrm{mL}$ volumetric flask, and then diluted with a buffer solution of pH 1.0 to mark boundaries. Measured absorbance of each solution at a maximum wavelength and $700 \mathrm{~nm}$, measured with distilled water as a blank. Dilution factor appropriate to the sample was determined by dissolving the sample with a buffer of $\mathrm{pH} 1.0$ to obtain maximum wavelength.

Furthermore $1 \mathrm{~mL}$ of solution preparation results were taken then put in a $10 \mathrm{~mL}$ volumetric flask and diluted with a buffer solution of pH 4.5 to mark boundaries. Absorbance of each solution at a maximum wavelength and $700 \mathrm{~nm}$ is measured with distilled water as a blank. Maximum wavelength is the maximum wavelength of cyanidin-3glucoside, while the wavelength of $700 \mathrm{~nm}$ to correct the sediment was still present in the sample. If the sample was absolutely clear that the absorbance at $700 \mathrm{~nm}$ is 0 . Absorbance of the sample has been dissolved $(A)$ is determined by the formula:

$\mathrm{A}=\left[\left(A_{\max }-A_{700}\right) \mathrm{pH} 1,0-\left(A_{\max }-A_{700}\right) \mathrm{pH} 4,5\right]$

Anthocyanin content in the sample is calculated using the formula:

Anthocyanin $\left(\mathrm{mg}^{\left.100 \mathrm{~g}^{-1}\right)}=\frac{A x M W \times D F \times 1000}{\varepsilon \times 1}\right.$

Description:

A = Absorbance

$\mathrm{MW}$ = the molecular weight (expressed as cyanidin-3glucoside), i.e. 449.2

DF = Dilution Factor

$\varepsilon \quad=$ Absorbtivitas molar coefficient: 26900 (expressed as cyanidin-3-glucoside)

\section{Total Phenol Measurement}

The sample extract of purple sweet potato chip to be tested is volumed of $1 \mathrm{~mL}$. $\mathrm{Na}_{2} \mathrm{CO}_{3}$ was added with a solution of $75 \mathrm{~g}^{-1} \mathrm{~L}^{-1} \mathrm{~mL}$ and FollinCiocalteau reagent (diluted $1: 10$ ) $5 \mathrm{~mL}$ and homogenized by vortex. The solution Incubated for an hour at room temperature with dark conditions. 
Total $2 \mathrm{~mL}$ of the extract was taken and put in a cuvette. Absorbance was measured at a wavelength of $765 \mathrm{~nm}$. It was calibrated with a standard curve of gallic acid to obtain total phenols in ppm GAE. Total phenol calculated by the formula:

$$
\mathrm{C}=\frac{C G A E x \mathrm{~V}}{G}
$$

Description:

C = total phenol content (ppm GAE)

CGAE = levels of total phenols in the form of gallic acid equivalents (ppm)

$\mathrm{V}=$ = the resulting extract volume $(\mathrm{mL})$

$\mathrm{G} \quad=$ the mass of material $(\mathrm{g})$

\section{Measurement of Total Dissolved Solids}

Sample of the purple sweet potato chip extract was prepared, and the prism refractometer was cleaned with distilled water, and then dried with tissue. Samples were taken with a pipette and dropped into the field prism, and we observed the number that passed the boundary of dark and light on the refractometer. The number showed the total dissolved solids in the sample.

\section{Measurement of Hue Value}

Samples of the fresh purple sweetpotato tuber were prepared and color reader was turned. Then the target reading $L, a^{*}, b^{*}$ was determined and measuring color. Then the color scale parameter was read $L^{*}$ (lightness) for brightness and $\mathrm{a} *, \mathrm{~b} *$ for chromaticity value. Changes color (hue) expressed in $\Delta \mathrm{H}$ can be calculated using the formula:

$$
\Delta \mathrm{H}=\Delta \mathrm{E} 2-\Delta \mathrm{L} 2-\Delta \mathrm{C} 2
$$

Where: $\quad \Delta \mathrm{L}=\mathrm{L}^{*} 0-\mathrm{L}^{*}$

$$
\Delta \mathrm{E}=\Delta \mathrm{L} 2+\Delta \mathrm{a} 2+\Delta \mathrm{b} 2
$$

Description:

$\Delta \mathrm{H}=$ changes color for a certain time

$\Delta \mathrm{E} \quad=$ changes value of $\mathrm{L}, \mathrm{a}, \mathrm{b}$ for a certain time

$\Delta \mathrm{L} \quad=$ changes value of $\mathrm{L}$ for a certain time

$\Delta C=$ changes value of $C$ for a certain time

$L^{*} 0=L$ values of samples at the initial condition

$\mathrm{L}^{*} \quad=\mathrm{L}$ value of sample for a certain time

$\Delta a \quad=$ changes value of $a^{*}$ for a certain time

$\Delta b=$ changes in the of $b^{*}$ for a certain time

$\mathrm{C}^{*} \quad=$ sample saturation value for a certain time

$\mathrm{C}^{*} 0=$ saturation value on initial conditions

\section{Data Collection Method}

This research used sampling with Randomize Block Design as data collection method. The reaserch use factorial experiment with two factors. The first factor is the time of immersion in liquid nitrogen in three levels $(0 ; 50 ; 60 ; 70$ sec), and the second factor is the thickness of plastic packaging with three levels $(0.07 \mathrm{~mm}$ and $0.10 \mathrm{~mm}$ ). This research resulted in 8 combinations with 3 repetitions, thus there are total 24 samples.

ANOVA was used in this research as data analysis method. Furthermore, if there is a significant result, the data will be analyzed by DMRT. The data werere analyzed with SPSS program. The best treatment will be explained by descriptive method.

\section{RESULT AND DISCUSSION}

The result included antioxidant activity, anthocyanin level, total phenol content, total dissolved solids content, and color (hue saturation value) of purple sweet potato antin 3 variety chips. Based on those parameter of physical and chemistry characters, the best treatment will be chosen.

\section{Antioxidant Activity}

The observation result of purple sweet potato antin 3 varieties chips with combination treatment of immersion time in liquid nitrogen and thickness of packing plastic showed that antioxidant activity was $24.83 \%$ - $45.33 \%$ (Fig. 1). Combination treatments caused different antioxidant activity level in each concentration. There was degradation of antioxidant activity after one month of storage.

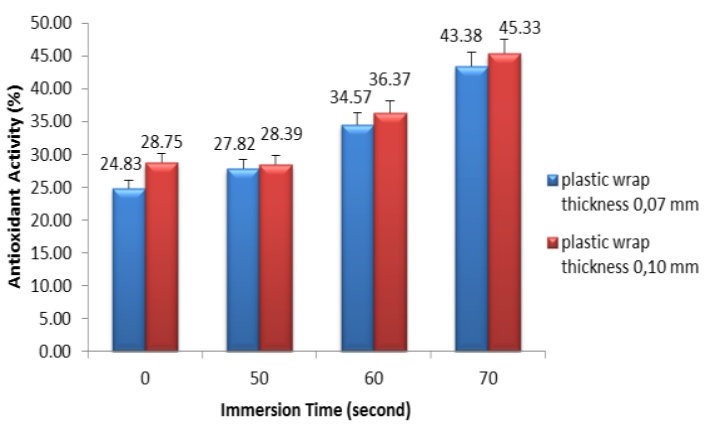

Figure 1. Average antioxidant activity of purple sweet potato var Antin 3 chips after one month of storage.

Antioxidant activity is strongly related to the anthocyanin substance which is found in purple sweetpotato. In this case, we measured antioxidant activity by DPPH method. In addition, the principal of antioxidant activity in sample changes the DPPH liquid color in methanol, the color chage from dark purple to pale orange. 
That phenomenon shows the sample ability to muffle the free radical activity which is represented by DPPH $[5,11]$. The antioxidant substance is anthocyanin, therefore, the higher anthocyanin substance the higher antioxidant activity.

The best immersion time showed that the immersion to liquid nitrogen process can maintain the anthocyanin substance as antioxidant. Freezing with liquid nitrogen will retain important compounds in frozen products [6]. While, the plastic wrap thickness factor which is not significanly influence on that case may be caused by the thickness level (which is not significantly different). However, previous study found the difference of plastic wrap thickness level will affect the ability of the plastic in protecting physical and chemical characteristic of wrapped-material [14].

\section{Total Anthocyanin Content}

The result of multi-analysis showed that the immersion time factor, the thickness of plastic wrap factor, and the interaction betweent those factors significantly influenced anthocyanin content. It indicated that the longer immersion time and the thicker plastic-wrap will increase the level of maintaing anthocyanin substance ability. The reduction of anthocyanin substance was $1.90-50.25 \%$ (Fig. 2).

The highest reduction of anthocyanin level was $50.25 \%$ which found in 0.00 second of immersion time and $0.07 \mathrm{~mm}$ of plastick-wrap thickness. Whereas, the smallest reduction of anthocyanin level was $1.90 \%$ found in 70 second of immersion time and $0.1 \mathrm{~mm}$ of plastick-wrap thickness. Those indicated that the longest of immersion time and the thinest plastic-wrap, the damage of anthocyanin substance was smallest.

The beneficial influence of immersion time (in liquid nitrogen) on anthocyanin level is strongly influenced by fast freezing process which produces micro crystal. Therefore, tuber tissue in purple sweetpotato is not damage after thawing process. Concerning the previous case, the thickness of plastic-wrap also gives significant effect on anthocyanin substance protection from contamination of other substance that damages not only the physical structure but also the chemical structure of the protected-material. Moreover, the packing method uses vacum packing with multilayer plastic which makes potential contamination is very small because multilayer plastic does not have pore as contamination trigger [15].

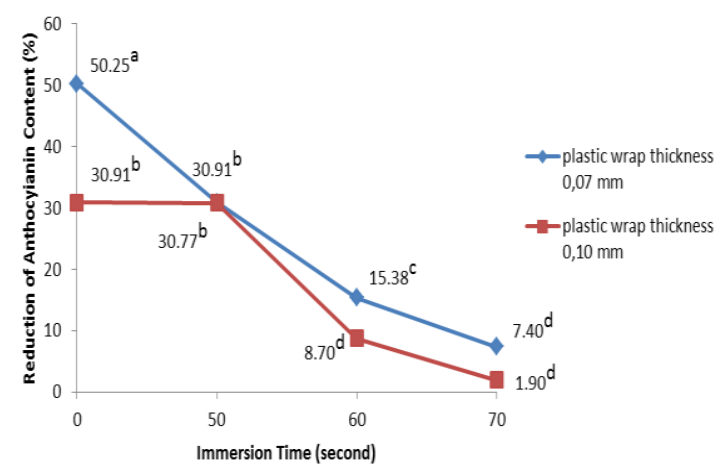

Figure 2. Reduction of anthocyianin content on purple sweet potato var Antin 3 chip after 1 month storage.

\section{Total Phenol Content}

The result of multi-analysis showed that immersion time factor, thickness of plastic wrap factor, and interaction betweent those factors significanly influenced the total phenol content. It was also indicated that the longer immersion time and the thicker plastic-wrap will increase the ability in preventing damage on the phenol substance.

After one month storage, the total phenol content was reduced as the effect of phenol substance degradation during the storage. The reduction of total phenol content was 4.54 $53.18 \%$ (Fig. 3 ).

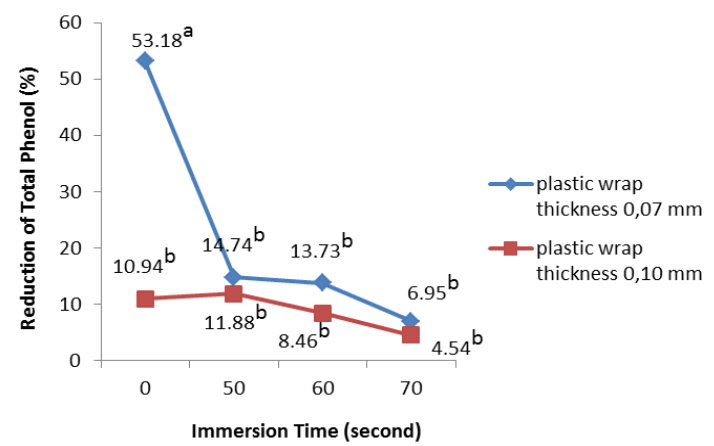

Figure 3. Reduction of total phenol content on purple sweet potato var Antin 3 chip after 1 month storage.

The highest reduction of total phenol content was $53.18 \%$ which was found in 0.00 second of immersion time and $0.07 \mathrm{~mm}$ of plastic-wrap thickness. While, the lowest reduction of total phenol content was $4.54 \%$ which was found in 70 second of immersion time and $0.1 \mathrm{~mm}$ of plastick-wrap thickness. These results showed that immersion on liquid nitrogen will maintain physicochemistry characteristic (one of them is phenol substance) of the material. Previous study reported on freezing process used liquid nitrogen 
in some level which were applied to cherry and apricot juice. The result showed that it can maintain the physicochemistry character of the materials [16].

In other case, the plastic-wrap thickness also influenced the total phenol contain. It showed that the thicker plastic-wrap, the higher ability in maintaining total phenol contain of wrapped-material. The process will be better if the wrapping process uses vacum method because it can maintain the physico-chemistry character of the material well. Related to this matter, Dewandari and Mulyawati [14] stated that the aplication of plastic to protect the wrapped-material from light, air or oxygen, heat transmission, contamination, and contact with other chemical substance which makes the food material/product maintain its water, fat and other beneficial substance.

\section{Total Dissolved Solid}

The result of total dissolved solid test after one month of storage showed that the reduction of total dissolved solid was $23.08-56.41 \%$ (Fig. 4). The higest reduction level of total dissolved solid by $56.41 \%$ found in 0.00 second of immersion time and $0.07 \mathrm{~mm}$ of plastic-wrap thickness. Otherwise, the lowest reduction level of total dissolved solid by $23.81 \%$ found in 70 second of immersion time and $0.1 \mathrm{~mm}$ of plastic-wrap thickness. Previous study found that storage at freezing temperatures decrease the minimum content of total dissolved solids [17].

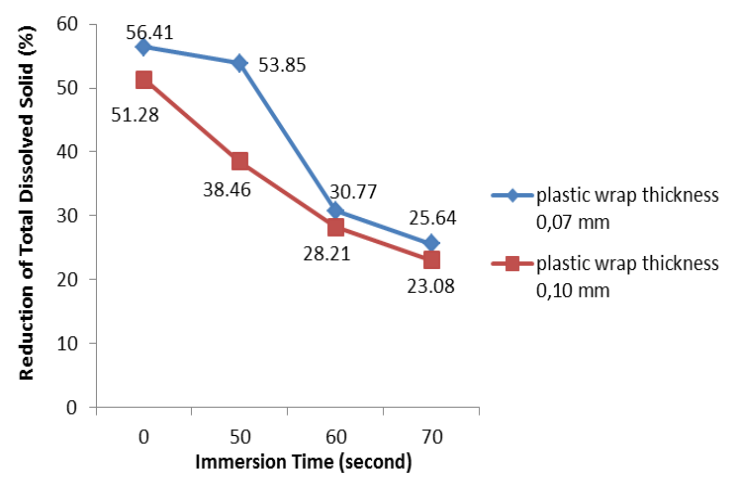

Figure 4. Total dissolved solid reduction of purple sweet potato var Antin 3 chip after 1 month storage.

Fast freezing process also reported to influence the ability of cherry in maintaining its total dissolved contain [18]. A study on the total dissolved contain in slices of pinaple Smooth Cayenne and Red Spanish which were stored in a $-18^{\circ} \mathrm{C}$, found that effective freezing process will increase the ability in maintaining total dissolved solid [17].

Other study reported the total dissolved solid of Puree Mango tended to decrease during 6 month storage when it wrapped by polyethylene plastic and freeze by immersion to liquid nitrogen [14]. The reduction of total dissolved solid in frozen product is the effect of the loss of beneficial components during freezing and storage process. Moreover, dehydration and reduction of sugar contain may also increase the reduction of total dissolven solid.

\section{Hue Saturation Value}

The observation result of hue saturation value after one month storage concluded that hue saturation value was 15.830 - 24.450 (Fig. 5). Based on Figure 5, hue saturation value is change after 1 month of storage. In this research, hue saturation value is related to red intencity which shows anthocyanin color in purple sweet potato. The higher hue saturation value showed the higher red intensity of purple sweet potato. This means that degradation levels of anthocyanins contained in the purple sweet potato was getting smaller. According to Winarno [19], the pigment concentration in a material determines the hue level.

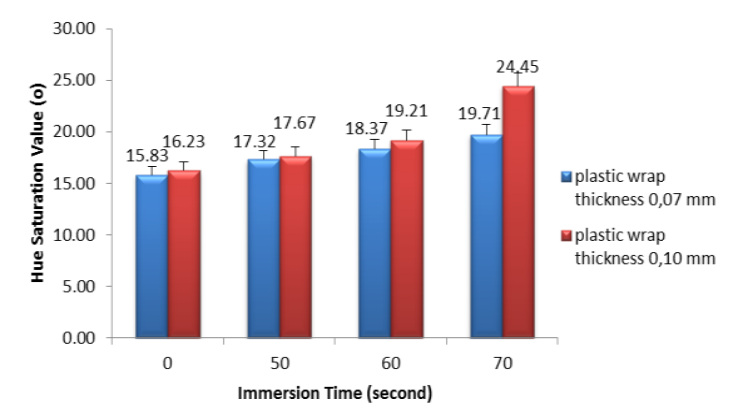

Figure 5. Average hue saturation of purple sweet potato var Antin 3 chip after 1 month storage.

Immersion with liquid nitrogen can maintain the anthocyanin substance which is known as color determiner of purple sweetpotato. Freezing with liquid nitrogen in whole fruit may damage the product, but for sliced-fruit that process can maintains the fruit appearance during 1 month of storage [6].

In the same case, plastick-wrap thickness also influences the ability in maintaining substances which are found in wrap material. The thicker plastict wrap, the higher ability in preventing the damage of material [14], e.g. maintaining the anthocyanin substance as antioxidant. 


\section{Determination of the best treatment}

The best treatment of this experiment was determoned by comparing observed-parameters of each treatment combinations (Table 1). The treatment combination which have highest value in each treatment is the best treatment.

The average of highest anthocyanin content

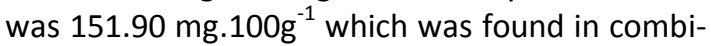
nation of immersion time 70 second and plasticwrap thickness $0.1 \mathrm{~mm}$. Next, the highest total phenol content was 4646.60 ppm GAE which was found in 70 seconds of immersion time and 0.1 $\mathrm{mm}$ of plastic-wrap thickness. The highest antioxidant activity was $45.33 \%$ which was found in 70 seconds of immersion time and $0.1 \mathrm{~mm}$ of plastic-wrap thickness. The highest level of total dissolved solid is $5.00 \%$ brix found in 70 seconds of immersion time and $0.1 \mathrm{~mm}$ of plastic-wrap thickness. The highest hue saturation value is $24.45^{\circ}$ hue found in 70 seconds of immersion time and $0.1 \mathrm{~mm}$ of plastic-wrap thickness.

Tabel 1. Highest value of each parameter after treatment

\begin{tabular}{|c|c|c|}
\hline Parameter & Result & Treatment \\
\hline $\begin{array}{l}\text { Antioxidant } \\
\text { Activity (\%) }\end{array}$ & 45.33 & $\begin{array}{l}\text { immersion time: } 70 \mathrm{~s} \\
\text { plastic-wrap thickness: } 0.1 \mathrm{~mm}\end{array}$ \\
\hline $\begin{array}{l}\text { Anthocyanin } \\
\left(\mathrm{mg} \cdot 100 \mathrm{~g}^{-1}\right)\end{array}$ & 151.90 & $\begin{array}{l}\text { immersion time: } 70 \mathrm{~s} \\
\text { plastic-wrap thickness: } 0.1 \mathrm{~mm}\end{array}$ \\
\hline $\begin{array}{l}\text { Total Phenol } \\
\text { (ppm GAE) }\end{array}$ & 4646.60 & $\begin{array}{l}\text { immersion time: } 70 \mathrm{~s} \\
\text { plastic-wrap thickness: } 0.1 \mathrm{~mm}\end{array}$ \\
\hline $\begin{array}{l}\text { Total } \\
\text { Dissolved } \\
\text { Solid (\%brix) }\end{array}$ & 5.00 & $\begin{array}{l}\text { immersion time: } 70 \mathrm{~s} \\
\text { plastic-wrap thickness: } 0.1 \mathrm{~mm}\end{array}$ \\
\hline Hue ('hue) & 24.45 & $\begin{array}{l}\text { immersion time: } 70 \mathrm{~s} \\
\text { plastic-wrap thickness: } 0.1 \mathrm{~mm}\end{array}$ \\
\hline
\end{tabular}

Those parameters showed that 70 seconds of immersion time and $0.1 \mathrm{~mm}$ of plastic-wrap thickness is the best treatment combination in this research because all five parameters shows the highest value in the combination of 70 seconds of immersion time and $0.1 \mathrm{~mm}$ of plastic-wrap thickness. The best treatment combination (immersion time and plastic-wrap thickness) was expected to become reference for further research on purple sweet potato chip products.

\section{CONCLUSION}

The best immersion time on liquid nitrogen was 70 seconds and the best plastic-wrap thickness was $0.1 \mathrm{~mm}$. Moreover, combination of between the factors is the most effective in preventing actioxidant damage of purple sweet potato chip during storage. Further research is needed on ready to serve purple sweet potato chip which through some process after fast freezing and storage.

\section{Acknowledgments}

The author would like to thank Mr. Wawan and the Artificial Insemination Research Center (BBIB) Singosari which has helped provide liquid nitrogen for the research.

\section{REFERENCES}

[1] Anonymous. 2013. Basis data statistik pertanian.http://aplikasi.pertanian.go.id/bdsp/ha sil_kom.asp. Accessed March 10 2014.

[2] Kumalaningsih, S., Harijono, Y.F. Amir. 2004. Pencegahan pencoklatan ubijalar untuk pembuatan tepung: kombinasi konsentrasi asam askorbat dan sodium acid pyrophosphate. J. Teknol. Pertanian. 5. 11-19.

[3] Yashimoto, M., S. Okuna, M. Yoshinaga, O. Yamakawa, M. Yamaguchi, J. Yamada. 1999. Antimutagenicity of sweet potato (Ipomoea batatas) root. Biosci. Biotech. Biochem. 63. 541-543.

[4] Cevallos-Casals, B.A., L.A. Cisneros-Zevallos. 2004. Stability of anthocyanin-based aqueous extract af Andean purple corn and redfleshed sweet potato compared to synthetic and natural colorants. Food Chem. 86. 6977.

[5] Hanani, E., A. Mun'im, R. Sekarini. 2005. Identifikasi senyawa antioksidan dalam spons Calispongia sp dari Kepulauan Seribu. Majalah Ilmu Kefarmasian. 3. 127-133.

[6] Broto, W, S.D. Sabari, Widyatmo, A.S.B. Dondy, Yulianingsih. 2002. Pembekuan cepat buah Mangga Gedong dan karakteristik mutunya selama penyimpanan beku. J. Hort. 12. 131-140.

[7] Rohanah, A. 2002. Pembekuan. Faculty of Agriculture. University of North Sumatera.

[8] Evahelda, B. Hamzah, Hasbi. 2002. Kajian mutu buah Manggis (Garcinia mangostana L.) selama penyimpanan menggunakan kemasan plastik. J. Agribis. Ind. Pert. 1. 1622.

[9] Tang, S.J., J.P. Kerry, D. Sheehan, D.J. Buckley. 2002. Antioksidative mechanizms of tea catechins in chicken meat systems. J. Food Chem. 76. 45-51.

[10] Giusti, M.M., R.E. Wrolstad. 2001. Unit F1.2: anthocyanins: characterization and measu- 
rement with UV-Visible spectroscopy. John Willey and Sons. New York. F1.2.1-1.2.13.

[11] Sharma, G.N. 2011. Phytochemical screening and estimation of total phenolic content in Aegle Marmelos seeds. J. Pharm. Clin. Res. 2. 27-29.

[12] AOAC. 1999. Official method of analysis $16^{\text {th }}$ Ed. Association of Official Analytical Chemist International. USA.

[13] Rahardjo, K.K.E., S.B. Widjanarko, 2015. Biosensor $\mathrm{pH}$ berbasis anthocyanin stroberi dan klorofil daun suji sebagai pendeteksi kebusukan fillet daging ayam. J. Pangan Agroindustri. 2. 333-344.

[14] Dewandari, K.T., D. Mulyawant. 2009. Pembekuan cepat puree mangga arumanis dan karakteristiknya selama penyimpanan. J. Pascapanen. 6. 27-33.

[15] Brown, E.W. 1992. Plastic in food pacakging, properties, design, and fabrication. Marcell Dekker, Inc. New York.

[16] Aider, M., D. Halleux. 2008. Production of concentrated cerry and apricot juices by cryoconcentration technology. J. Food Sci. Tech. 41. 1768-1775.

[17] Bartolome, A.P., P. Ruperez, C. Fuster. 1995. Changes in soluble sugars of two pineapple fruit cultivars during frozen storage. J. Food Chem. 56. 163-165.

[18] Wolfram, B., C. Wilcke, 1992. Evaluation of the processing suitability of frozen sour cherries (breeding material). Erwerbsobstbau. 34. 173-176.

[19] Winarno, F.G. 2002. Kimia pangan dan gizi. Gramedia Pustaka Utama. Jakarta. 